\title{
Front Matter: Volume 8874
}

, "Front Matter: Volume 8874," Proc. SPIE 8874, Laser Communication and Propagation through the Atmosphere and Oceans II, 887401 (10 October 2013); doi: 10.1117/12.2048479

EDIE Event: SPIE Optical Engineering + Applications, 2013, San Diego, California, SPIE. United States 


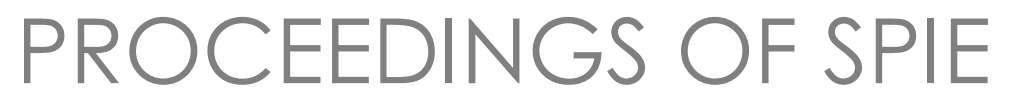

\title{
Laser Communication and Propagation through the Atmosphere and Oceans II
}

\author{
Alexander M. J. van Eijk \\ Christopher C. Davis \\ Stephen M. Hammel \\ Editors
}

26-27 August 2013

San Diego, California, United States

Sponsored and Published by

SPIE 
The papers included in this volume were part of the technical conference cited on the cover and title page. Papers were selected and subject to review by the editors and conference program committee. Some conference presentations may not be available for publication. The papers published in these proceedings reflect the work and thoughts of the authors and are published herein as submitted. The publisher is not responsible for the validity of the information or for any outcomes resulting from reliance thereon.

Please use the following format to cite material from this book:

Author(s), "Title of Paper," in Laser Communication and Propagation through the Atmosphere and Oceans II, edited by Alexander M. J. van Eijk, Christopher C. Davis, Stephen M. Hammel, Proceedings of SPIE Vol. 8874 (SPIE, Bellingham, WA, 2013) Article CID Number.

ISSN: 0277-786X

ISBN: 9780819497246

Published by

SPIE

P.O. Box 10, Bellingham, Washington 98227-0010 USA

Telephone +1 3606763290 (Pacific Time) · Fax +1 3606471445

SPIE.org

Copyright (c) 2013, Society of Photo-Optical Instrumentation Engineers.

Copying of material in this book for internal or personal use, or for the internal or personal use of specific clients, beyond the fair use provisions granted by the U.S. Copyright Law is authorized by SPIE subject to payment of copying fees. The Transactional Reporting Service base fee for this volume is $\$ 18.00$ per article (or portion thereof), which should be paid directly to the Copyright Clearance Center (CCC), 222 Rosewood Drive, Danvers, MA 01923. Payment may also be made electronically through CCC Online at copyright.com. Other copying for republication, resale, advertising or promotion, or any form of systematic or multiple reproduction of any material in this book is prohibited except with permission in writing from the publisher. The CCC fee code is 0277-786X/13/\$18.00.

Printed in the United States of America.

Publication of record for individual papers is online in the SPIE Digital Library.

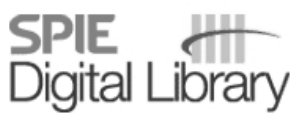

SPIEDigitallibrary.org

Paper Numbering: Proceedings of SPIE follow an e-First publication model, with papers published first online and then in print and on CD-ROM. Papers are published as they are submitted and meet publication criteria. A unique, consistent, permanent citation identifier (CID) number is assigned to each article at the time of the first publication. Utilization of CIDs allows articles to be fully citable as soon as they are published online, and connects the same identifier to all online, print, and electronic versions of the publication. SPIE uses a six-digit CID article numbering system in which:

- The first four digits correspond to the SPIE volume number.

- The last two digits indicate publication order within the volume using a Base 36 numbering

system employing both numerals and letters. These two-number sets start with 00, 01, 02, 03, 04, $05,06,07,08,09,0 A, 0 B \ldots 0 Z$, followed by 10-1Z, 20-2Z, etc.

The CID Number appears on each page of the manuscript. The complete citation is used on the first page, and an abbreviated version on subsequent pages. Numbers in the index correspond to the last two digits of the six-digit CID Number. 


\title{
Contents
}

\author{
vii Conference Committee \\ ix Introduction
}

\section{SESSION 1 PROPAGATION AND MODELING I}

887402 Deep turbulence propagation of a Gaussian-beam wave in anisotropic non-Kolmogorov turbulence (Invited Paper) [8874-1]

L. C. Andrews, R. L. Phillips, R. Crabbs, T. Leclerc, CREOL, The College of Optics and Photonics, Univ. of Central Florida (United States)

887405 Wave optics simulation for beams with spatially varying coherence properties [8874-4]

X. Xiao, D. G. Voelz, New Mexico State Univ. (United States)

887406 Measurement system for analyzing the spectral radiation pattern of light sources for FSO systems [8874-5]

P. Pezzei, N. Stiebler, T. Plank, Technische Univ. Graz (Austria); J. Poliak, Brno Univ. of

Technology (Czech Republic); E. Leitgeb, M. Löschnigg, Technische Univ. Graz (Austria)

\section{SESSION 2 MODELING II AND UV SYSTEMS}

887408 Retrieval of structure functions of air temperature and refractive index from large eddy simulations of the atmospheric boundary layer [8874-6]

C. Wilson, The Univ. of Oklahoma (United States); A. M. J. van Eijk, TNO (Netherlands) and LUNAM, CNRS, Univ. Ecole Centrale de Nantes (France); E. Fedorovich, The Univ. of Oklahoma (United States)

887409 GPS synchronized UV communication system performance based on USRP [8874-7] L. Liao, G. Chen, Univ. of California, Riverside (United States); B. M. Sadler, U.S. Army Research Lab. (United States); Z. Li, Univ. of California, Riverside (United States)

\section{SESSION $3 \quad$ ATMOSPHERIC EFFECTS AND POINTING}

8874 OC Pointing, acquisition, and tracking considerations for mobile directional wireless communications systems [8874-10]

J. Rzasa, Univ. of Maryland, College Park (United States); M. C. Ertem, Univ. Research Foundation (United States); C. C. Davis, Univ. of Maryland, College Park (United States)

8874 OD An innovative modulating retro-reflector for free-space optical communication [8874-11] E. Rosenkrantz, S. Arnon, Ben-Gurion Univ. of the Negev (Israel) 
$8874 \mathrm{OE}$ Comparison and evaluation of the laser beam-shaping techniques [8874-12]

P. Barcik, L. Hudcova, O. Wilfert, Brno Univ. of Technology (Czech Republic);

J. L. Arce-Diego, F. Fanjul-Velez, I. Salas-Garcia, N. Ortega-Quijano, Univ. de Cantabria (Spain)

8874 OF Extracting atmospheric turbulence and aerosol characteristics from passive imagery [8874-13]

C. N. Reinhardt, D. Wayne, K. McBryde, G. Cauble, Space and Naval Warfare Systems Command (United States)

\section{SESSION 4 CHARACTERIZATION OF TURBULENCE}

$8874 \mathrm{OH} \quad$ A novel method for measuring atmospheric transmission using a modulated laser source [8874-15]

D. T. Wayne, C. N. Reinhardt, K. McBryde, G. Cauble, Space and Naval Warfare Systems Command (United States)

$8874 \mathrm{Ol} \quad$ Modified plenoptic camera for phase and amplitude wavefront sensing [8874-16]

C. Wu, C. C. Davis, Univ. of Maryland, College Park (United States)

$88740 \mathrm{~J}$ Multifractality and the effect of turbulence on the chaotic dynamics of a HeNe laser [8874-17]

D. Gulich, L. Zunino, Ctr. de Investigaciones Ópticas (Argentina) and Univ. Nacional de La Plata (Argentina); D. Pérez, Pontificia Univ. Católica de Valparaíso (Chile); M. Garavaglia, Ctr. de Investigaciones Ópticas (Argentina) and Univ. Nacional de La Plata (Argentina)

\section{SESSION $5 \quad$ PROPAGATION STUDIES IN WATER AND THE ATMOSPHERE}

8874 OK Affordable underwater wireless optical communication using LEDs (Invited Paper) [8874-18] V. Pilipenko, S. Arnon, Ben-Gurion Univ. of the Negev (Israel)

$8874 \mathrm{OL} \quad$ New technologies in underwater optical acquisition and tracking providing new possibilities for laser communication [8874-19]

M. Tausendfreund, Cassidian Optronics GmbH (Germany)

8874 OM Recovery of LED diode optical spectrum [8874-20]

J. Vitasek, J. Latal, P. Siska, J. Skapa, M. Papes, V. Vasinek, Technical Univ. of Ostrava (Czech Republic)

$8874 \mathrm{ON}$ Measurements and modeling of resolved laser radiometry in the maritime environment [8874-21]

J. S. deGrassie, I. Bendall, J. Cole, G. Cauble, Space and Naval Warfare Systems Command (United States) 
887400 Using speckle imaging techniques as a starting point for MFBD scene reconstruction from long horizontal-path, turbulence-degraded imagery (Invited Paper) [8874-23]

J. P. Bos, G. Archer, M. C. Roggemann, Michigan Technological Univ. (United States)

8874 OP Simulating video through turbulence [8874-24]

K. McBryde, K. Gibson, Space and Naval Warfare Systems Command (United States)

$88740 Q$ The feasibility of vision systems to form free-space optical links [8874-25]

M. Eslami, C.-H. Chen, J. Rzasa, S. D. Milner, C. C. Davis, Univ. of Maryland, College Park (United States)

8874 OS Detection of non-standard atmospheric effects in FSO systems [8874-27]

O. Wilfert, J. Poliak, P. Barcík, Brno Univ. of Technology (Czech Republic); J. L. Arce-Diego,

F. Fanjul-Vélez, I. Salas-García, N. Ortega Quijano, Univ. de Cantabria (Spain)

\section{SESSION 7 TURBULENCE MODELING}

8874 OT Improved Sparse Spectrum model for the turbulent phase (Invited Paper) [8874-28]

M. Charnotskii, Zel Technologies, LLC (United States) and National Oceanic and

Atmospheric Administration (United States)

8874 OU Geometrical Monte Carlo simulation of atmospheric turbulence [8874-29]

D. Yuksel, H. Yuksel, Bogaziçi Üniv. (Turkey)

8874 OV Geometrical optics analysis of atmospheric turbulence [8874-30]

C. Wu, C. C. Davis, Univ. of Maryland, College Park (United States)

8874 OW Geometrical modeling of optical phase difference for analyzing atmospheric turbulence [8874-31]

D. Yuksel, H. Yuksel, Bogaziçi Üniv. (Turkey)

\section{SESSION 8 CODING AND NETWORKING}

8874 OX Predicting network instabilities in mobile directional wireless networks [8874-32]

D. M. Coleman, S. D. Milner, C. C. Davis, Univ. of Maryland, College Park (United States)

8874 OY Precoder design for indoor visible light communications with multiple RGB LEDs [8874-33]

Q. Gao, T. Lang, F. Bo, G. Chen, Y. Hua, Univ. of California, Riverside (United States)

POSTER SESSION

887410 Propagation and split of the filamentation of femtosecond pulses in air by multiphase screen method [8874-22]

J. Zu, Q. Huang, X. Zhou, P. Zou, Y. Zheng, T. Yu, Shanghai Institute of Optics and Fine Mechanics (China); Y. Wang, Y. Gao, Heilongjiang Univ. (China) 
$887411 \quad$ Space qualified photon counting detector package [8874-35]

J. Blazej, I. Prochazka, Czech Technical Univ. in Prague (Czech Republic); J. Kodet, Czech Technical Univ. in Prague (Czech Republic) and Technische Univ. München (Germany)

887412 Prototyping FM data demodulation in free-space optical communication systems using discrete wavelet transformation [8874-36]

L. Tran, E. El-Araby, N. Namazi, The Catholic Univ. of America (United States)

887413 Phase-space distribution of optical field intensity of laser beam propagation through atmospheric turbulence [8874-37]

W. LU, J. Sun, D. XU, X. Ma, B. Li, L. Liu, Shanghai Institute of Optics and Fine Mechanics (China)

887414 The effect of the light size and telecommunication rate on homodyne detection efficiency in the satellite-to-ground laser communication [8874-38]

X. Ma, J. Sun, Y. Zhi, W. Lu, Q. Xu, L. Liu, Shanghai Institute of Optics and Fine Mechanics (China)

887415 Measurement and modeling of the effects of atmospheric turbulence on coherent laser propagation characteristics and FSO system performance [8874-39]

J. Zhou, W. Lu, J. Sun, L. Liu, Shanghai Institute of Optics and Fine Mechanics (China)

Author Index 


\title{
Conference Committee
}

\author{
Program Track Chairs
}

Stephen M. Hammel, Space and Naval Warfare Systems Command (United States)

Alexander M. J. van Eijk, TNO Defence, Security and Safety (Netherlands)

\section{Conference Chairs}

Alexander M. J. van Eijk, TNO Defence, Security and Safety (Netherlands) Christopher C. Davis, University of Maryland, College Park (United States) Stephen M. Hammel, Space and Naval Warfare Systems Command (United States)

Arun K. Majumdar, Naval Air Warfare Center Weapons Division (United States)

\section{Conference Program Committee}

Larry C. Andrews, University of Central Florida (United States) Jaime Anguita, Universidad de Los Andes (Chile) Shlomi Arnon, Ben-Gurion University of the Negev (Israel) Mikhail S. Belen'kii, Trex Enterprises Corporation (United States) Matthew M. Bold, Lockheed Martin Space Systems Company (United States)

Robert J. Grasso, Northrop Grumman Electronic Systems (United States) Jony Jiang Liu, U.S. Army Research Laboratory (United States) Vladimir B. Markov, Advanced Systems \& Technologies, Inc. (United States)

Stuart D. Milner, University of Maryland, College Park (United States)

Dominic C. O'Brien, University of Oxford (United Kingdom)

Ronald L. Phillips, Florida Space Institute (United States)

William S. Rabinovich, U.S. Naval Research Laboratory (United States)

Karin Stein, Fraunhofer-Institut für Optronik, Systemtechnik und Bildauswertung (Germany)

Michael T. Valley, Sandia National Laboratories (United States)

Thomas Weyrauch, University of Dayton (United States)

Otakar Wilfert, Brno University of Technology (Czech Republic)

\section{Session Chairs}

1 Propagation and Modeling I

Christopher C. Davis, University of Maryland, College Park (United States)

Alexander M. J. van Eijk, TNO Defence, Security and Safety (Netherlands)

2 Modeling II and UV Systems

Heba Yuksel, Bogaziçi Üniversity (Turkey) 
3 Atmospheric Effects and Pointing

Stephen M. Hammel, Space and Naval Warfare Systems Command (United States)

4 Characterization of Turbulence

Jeremy P. Bos, Michigan Technological University (United States)

Colin Reinhardt, Space and Naval Warfare Systems Command (United States)

5 Propagation Studies in Water and the Atmosphere

Mikhail I. Charnotskii, National Oceanic and Atmospheric Administration (United States)

Olga Korotkova, University of Miami (United States)

6 Imaging and Beam Propagation

Shlomi Arnon, Ben-Gurion University of the Negev (Israel)

Etai Rosenkrantz, Ben-Gurion University of the Negev (Israel)

Christopher C. Davis, University of Maryland, College Park (United States)

7 Turbulence Modeling

Stephen M. Hammel, Space and Naval Warfare Systems Command (United States)

8 Coding and Networking

Christopher C. Davis, University of Maryland, College Park (United States)

Alexander M. J. van Eijk, TNO Defence, Security and Safety (Netherlands) 


\section{Introduction}

This volume contains the papers submitted and accepted as full manuscripts following presentation at the second Conference on Laser Communication and Propagation through the Atmosphere and Oceans II. This new conference is the second in a series that combined previous conferences on Atmospheric Optics: Turbulence and Propagation, and Free-Space and Atmospheric Laser Communications. Free space optical (FSO) communication is now a mature field, but many exciting fundamental and technological challenges remain to improve its performance in a range of scenarios. The data rates provided by FSO links continue to increase in both long and short range applications. There continues to be great interest in simulations and experiments that characterize the optical properties of the turbulent atmosphere, including in seriously obscured conditions.

There is a need to simulate the effects of turbulence on imaging through the atmosphere. Because of anisoplanatism effects, the image-distorting effects of turbulent atmospheres vary over small angular changes, and adequate simulations become computationally expensive. Speckle imaging techniques can be used to improve the quality of images affected by atmospheric turbulence. Very long range terrestrial links through the atmosphere can experience severe scintillation caused by atmospheric turbulence, which presents significant challenges in beam pointing and leads to deep fades. Turbulence can even be used to induce interesting chaotic dynamics effects that can be analyzed by fractal techniques.

Pointing, acquisition, and tracking of narrow beams, whether FSO or RF remains an important issue. Forward error correction, interleaving, and packet-level correction codes can also improve the performance of FSO links. Clever transceiver implementations and the right modulation schemes show promise for improved link performance. Non-line-of-sight links using solar blind UV radiation scattered from transmitter to receiver open interesting communication scenarios.

FSO communication links are now being designed for different specialized scenarios. There is increased interest in the use of light emitting diodes for indoor communications, particularly for downloading of data, and in clever schemes like MIMO for improving their performance. Underwater optical communications can provide networking of sensors for monitoring water quality and the effects of climate change, as well as for short range data transfer. The use of directional radiofrequency communications as an alternative to FSO can improve link and network availability, and opens up interesting opportunities for network modeling. The interesting issues described above are addressed in papers published in this volume. A number of papers describe new characterization techniques for atmospheric transmission and measurement of the spectral characteristics of LED sources. At a fundamental level, several papers address modeling of the effects 
of the atmosphere on propagating beam waves, using both wave optic and geometrical optic approaches, where atmospheric properties can be measured, and correlated with theoretical models describing phenomena such as obscuration, beam wander, scintillation and image motion.

Alexander M. J. van Eijk Christopher C. Davis Stephen M. Hammel 